\title{
Effect of additives on flexible PVC foam formation
}

\author{
H. Demir*, M. Sipahioğlu, D. Balköse, S. Ülkü \\ Department of Chemical Engineering, Izmir Institute of Technology, Gulbahce Campus, 35430 Urla Izmir, Turkey
}

\section{A R T I C L E I N F O}

Article history:

Received 27 October 2006

Received in revised form

19 April 2007

Accepted 19 April 2007

Keywords:

PVC

Foam

Luffa cylindrical

Natural zeolite

Compression

\begin{abstract}
A B S T R A C T
In this study, effects of $\mathrm{Ca} / \mathrm{Zn}$ stearate and organotin heat stabilizers and zeolite, $\mathrm{CaCO}_{3}$, cellulose and luffa flours fillers, and their concentrations $(2.5,5,10$ and $20 \%$ by weight) on production of flexible PVC foams by chemical blowing agent, azodicarbonamide were investigated. Foam morphology, foam density, compressive mechanical properties and water uptake capacities of samples were determined. Morphology of the sample without any filler showed that employment of Ca stearate and Zn stearate heat stabilizers instead of organotin stabilizers increases foam formation and decreases pore sizes and regularity in pore size distribution. Foams having organotin stabilizer were more resistant to heat than the ones with $\mathrm{Ca} / \mathrm{Zn}$ stearate for long heating periods. Foams, including organotin-based heat stabilizers, have compact structure. It was observed that, samples containing zeolite, $\mathrm{CaCO}_{3}$, cellulose or luffa flour had lower pore volume but higher Young's modulus and stress values compared to unfilled samples.
\end{abstract}

ㄷ 2007 Elsevier B.V. All rights reserved.

\section{Introduction}

Use of polymeric foam in today's technology continues to grow at a rapid pace throughout the world. Numerous reasons for this growth include the light weight, excellent strength/weight ratio, superior insulating abilities, and energy absorbing performance and comfort features of polymeric foams. Foams can be prepared from virtually any polymer; all that is necessary is the introduction or generation of a gas within the polymer matrix. Selection of polymers suitable for industrial foam applications depends upon their properties, their ease of manufacture and the economics of the foaming system. Application areas of polymeric foams are furniture, transportation, bedding, carpet underlay, packaging, textiles, toys, gasket, sport applications and insulation appliances. Mechanical properties of foamed polymers change according to different additives. Initiators are the additives, that cause the foam formation (Berins et al., 1982; Brathun and Zingsheim, 1991).
Foams can be flexible or rigid due to their glass transition temperature, which in turn depends upon their chemical composition, the degree of crystallinity and the degree of cross-linking. The cell geometry may be opened or closed cell. The open cell foams are best for car seating, furniture; bedding and acoustical insulation, among other uses, and are generally flexible. The closed cell foams are most suitable for thermal insulation and are generally rigid (Gaechter and Müller, 1993; Hensen, 1997; Matuana et al., 1998).

Additives which are used in the production of the foams improve the endurance and hardness, and protect foams from the environmental effects. The cellulose-based fillers (such as cellulose, wood flour, luffa, etc.) generally used for increasing biodegradability of plastics. The inorganic-based fillers (i.e. calcium carbonate, zeolite, clay, etc.) used for developing the structure of foams. In order to compensate for the lowered impact strength and ductility of wood flour composites due to the incorporation of wood flour in the PVC matrix, Matuana et al. (Matuana et al., 1998) successfully

\footnotetext{
* Corresponding author. Tel.: +90 232750 6680; fax: +90 2327506645. E-mail address: hasandemir@iyte.edu.tr (H. Demir). 
introduced a microcellular-foamed structure using a batch process. The mechanical properties of these materials indicated that the microcellular structures improved the impact strength of rigid PVC/wood flour composites dramatically while lowering the density of the artificial wood to the desired range of $0.6-0.8 \mathrm{~g} / \mathrm{cm}^{3}$ (Matuana et al., 1998; Mengeloglu and Matuana, 2001; Patterson, 2001; Saechtling, 1987; Yanez-Flores et al., 2000).

Since PVC undergoes dehydrochlorination by heating, heat stabilizers should be added especially mixed metal soap heat stabilizers such as $\mathrm{Ca} / \mathrm{Zn}$ stearates or organotin compounds. The heat stabilizers also affect the rate of decomposition of chemical blowing agents (Arkiş and Balköse, 2005; Balköse et al., 2001).

The objective of this study is to investigate effects of different fillers on the foam formation, density, mechanical properties, water uptake and morphology of the flexible PVC foam. Moreover, it was aimed to investigate effects of different heat stabilizers which are $\mathrm{Ca} / \mathrm{Zn}$ stearate and organotin. For this purpose, different compositions of fillers; zeolite, $\mathrm{CaCO}_{3}$, cellulose powder or luffa flour were added to PVC plastisols that consist of PVC base, dioctyl phthalate (DOP, plasticizers), azodicarboxamide (AZD, blowing agent) and Ca-Zn stearate or organotin heat stabilizers. These foams were compared with flexible PVC foam without any filler to observe the effects of concentration of the filler. Thus, tailoring the properties of the flexible foams would be possible.

\section{Experimental procedure}

\subsection{Materials}

Plastisol consists of emulsion type of PVC (from Petkim, Petvinil 37/74), dioctyl phthalate (Merck Co.) and azodicarboxamide (Merck Co.). Organotin stabilizer (LSN117C) and Ca/Zn stearate (Akdeniz Co.) were added into formulation as heat stabilizers. Pure cellulose (from Aldrich Co., with average particle size of $2 \mu \mathrm{m}$ ), natural luffa fiber (from specialty shops with average particle size between 75 and $150 \mu \mathrm{m}$ ), natural zeolite (Clinoptiolite, from Gördes, with average particle size less than $45 \mu \mathrm{m}$ ) and calcium carbonate (from Aldrich Co., with average particle size of $2 \mu \mathrm{m}$ ) were added to plastisol as fillers.

\subsection{Preparation of polymeric foam}

In this experiment, PVC foam samples were produced from PVC plastisol. At first, PVC plastisol was prepared in a mechanical stirrer by mixing 100 parts emulsion PVC, 80 parts DOP, 2 parts AZD and 2 parts $\mathrm{Ca}-\mathrm{Zn}$ stearate heat stabilizers combination or organotin heat stabilizer. Then $2.5,5,10$ or $20 \%$ (by weight) fillers were added and mixed with mechanical stirrer until obtaining a homogeneous mixture.

After preparing the plastisol, mixtures were poured in molds of $5 \mathrm{~cm} \times 5 \mathrm{~cm} \times 2 \mathrm{~cm}$ sizes and processed in oven at $190^{\circ} \mathrm{C}$ for $25 \mathrm{~min}$. The azodicarboxamide (chemical blowing agent) decomposes during plasticizing, releasing ammonia gas $\left(\mathrm{NH}_{3}\right)$ that dissolves in the plastisol. The gas must remain dissolved in the melt until curing is accompanished.

\subsection{Density and pore volume}

Density of PVC foams was measured by using Sartorius density measurement kit (model YDK01). Ethyl alcohol was used as the liquid causing buoyancy. To determine the sample's buoyancy, float sample was immersed by a sieve. The negative weight displayed by the balance corresponded to the buoyancy acting on the sample in the liquid.

The formed by using following calculation procedure taken from manual of Sartorius AG (Sartorius, 1992). Density of foam samples was calculated by using Eq. (1).

$\rho=\frac{\mathrm{W}_{\mathrm{a}} \rho_{\mathrm{fl}}}{0.99983 \mathrm{G}}+0.0012$

where $G$ is the buoyancy force, $\rho_{\mathrm{fl}}$ the fluid density, $\rho$ the foam density and $W_{a}$ is the dry weight of foam.

The percentage of the volume of pores of the foam samples was calculated by using Eq. (2).

$\mathrm{V}_{\text {total pore }}=\left(1-\frac{\rho}{\rho_{\text {Theoretical }}}\right) \times 100$

The percentage of the volume on the surfaces of the specimen was calculated according to the following procedure. First the geometric volume of the specimen $\mathrm{V}$ was calculated by Eq. (3).

The total geometric surface area of the specimen, $A$, was calculated by Eqs. (2) and (3).

$A=2(l w+l h+h w)$

The percentage volume of the surface cells opened by sample preparation, $V_{\text {surface pore, }}$ was determined from Eq. (4).

$\mathrm{V}_{\text {surface pore }}=\frac{\mathrm{At}}{1.14} \times 100$

where $t$ is the average chord length. It was determined from the relationship between $t$ and the average cell size, $d$. The average cell size, $d$, was determined from the SEM micrograph. The relationship is given in Eq. (5).

$t=\frac{d}{1.626}$

The open pore volume inside the specimen, in other words the opened channels, $V_{\text {opened channel }}$ in the specimen was calculated with Eq. (6).

$\mathrm{V}_{\text {opened channel }}=\frac{\mathrm{W}_{\text {wet }}-\mathrm{W}_{\mathrm{a}}}{\rho_{\mathrm{fl}}}$

where $\mathrm{W}_{\text {wet }}$ is the wet weight of foam.

The total open pore percentages of the foams were calculated by summing open pore volume percentages on the surfaces of the specimen and inside the specimen with Eq. (7).

$V_{\text {total open pore }}=V_{\text {surface pore }}+V_{\text {opened channel }}$

The closed pore percentage of the foam is the rest of the total pore volume percentage after subtracting the total open 
pore volume percentage and was calculated by Eq. (8).

$\mathrm{V}_{\text {closed pore }}=\mathrm{V}_{\text {total pore }}-\mathrm{V}_{\text {total open pore }}$

\subsection{Mechanical test}

The mechanical test method used was ASTM D1621-73 standard test method with the height/diameter ratio of 1 (ASTM, 1979). This test method provides information regarding the behavior of cellular materials under compressive loads. The samples of PVC foam were cut by a sharp blade into square blocks with $10 \mathrm{~mm} \times 10 \mathrm{~mm} \times 10 \mathrm{~mm}$ dimensions. Three specimens were used for the compression tests. The stress-strain diagrams of the samples were obtained using mechanical test machine (Testometric instrument) $100 \mathrm{kgf}$ and the cross-head speed was $3 \mathrm{~mm} / \mathrm{min}$. The test was stopped when machine gives overloading alarm. Deformation data and complete loaddeformation curve were taken from Wintest software program supplied from Testometric Co.

\subsection{Water uptake test}

The samples were cut into $10 \mathrm{~mm} \times 10 \mathrm{~mm} \times 10 \mathrm{~mm}$ cubic shapes. First, the samples were dried at $60^{\circ} \mathrm{C}$ for overnight till constant weight was obtained. Then they were immersed into static distilled water bath at $25^{\circ} \mathrm{C}$ to observe the sorption of water. Mass uptake values of the samples were measured periodically by removing them from the water bath and wiping with tissue paper.

\subsection{Scanning electron microscopy (SEM)}

Scanning electron microscopy (Philips XL-305 FEG-SEM) was employed to study the deformation mechanism of the cell structures and view the internal configuration of the cell. The cross-sections of PVC foams were prepared by sharp bending and then coated by a gold film.

\section{Results and discussion}

In chemical blowing process, the blowing agent gave $\mathrm{N}_{2}$ and accumulation of this gas around the nucleating agents caused expansion of plastisol mixture. The plastisol became a plastigel by the diffusion of plasticizers into PVC particles by heat above $140^{\circ} \mathrm{C}$.

At $190^{\circ} \mathrm{C}$ all these processes occured simultaneously. As the concentrations of fillers were increased the plastisols had
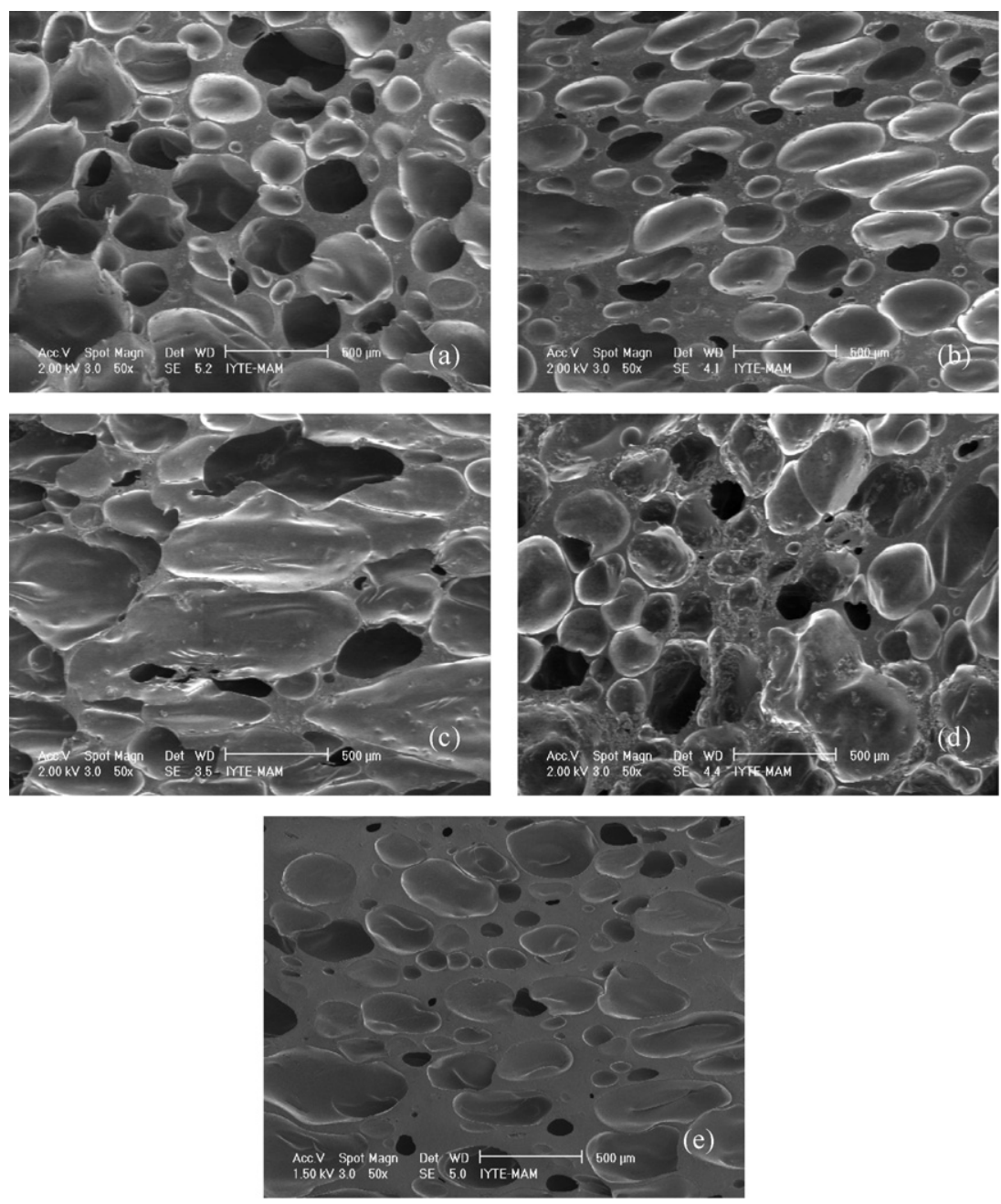

Fig. 1 - SEM micrographs of $\mathrm{Ca} / \mathrm{Zn}$ stearate stabilized PVC foams with: (a) $2.5 \%$, (b) $5 \%$, (c) $10 \%$ and (d) $20 \% \mathrm{CaCO}_{3}$, and (e) without additives. 


\begin{tabular}{lccc}
\multicolumn{3}{l}{$\begin{array}{l}\text { Table 1 - Average pore sizes and deviations of the } \mathbf{~ C a} / \mathbf{Z n} \\
\text { stearate stabilized samples }\end{array}$} \\
\hline Filler type & $\begin{array}{c}\text { Concentration } \\
(\%)\end{array}$ & $\begin{array}{c}\text { Average pore } \\
\text { size }(\mu \mathrm{m})\end{array}$ & $\begin{array}{c}\text { Standard } \\
\text { deviation }(\mu \mathrm{m})\end{array}$ \\
\hline Pure PVC & 0 & 205.9 & 130.8 \\
Zeolite & 2.5 & 220.5 & 134.6 \\
& 5 & 194.3 & 135.5 \\
& 10 & 211.0 & 180.6 \\
$\mathrm{CaCO}_{3}$ & 20 & 223.7 & 208.4 \\
& 2.5 & 280.6 & 108.2 \\
& 5 & 337.3 & 87.6 \\
Cellulose $^{2}$ & 10 & 418.4 & 280.6 \\
& 20 & 289.3 & 145.1 \\
& 2.5 & 137.2 & 99.6 \\
& 5 & 95.4 & 66.7 \\
Luffa & 10 & 78.7 & 49.2 \\
& 20 & 109.0 & 86.3 \\
& 2.5 & 110.8 & 76.7 \\
& 5 & 98.3 & 58.9 \\
& 10 & 85.2 & 53.0 \\
& 20 & 72.6 & 57.3 \\
& & &
\end{tabular}

higher viscosity and their expansion with gases became more difficult. Thus, it was expected to have smaller foam cell diameter with increasing filler content. Release of air from the pores of the fillers and catalytic activity of fillers on AZD decomposition had positive effect in increasing the total volume of the released gases. Compatibility of the surface of the fillers with plastisols was also a parameter affecting mechanical properties of plastigels obtained. Fillers could cause incomplete gelation of plastisols in case of bad adhesion between fillers and plastisols. Since cellulose, zeolite and luffa powders adsorb moisture in appreciable amounts and calcite is

\begin{tabular}{lccc}
\hline \multicolumn{3}{l}{$\begin{array}{l}\text { Table 2 - Average pore sizes and deviations of the } \\
\text { organotin stabilized samples }\end{array}$} \\
\hline Filler type & $\begin{array}{c}\text { Concentration } \\
(\%)\end{array}$ & $\begin{array}{c}\text { Average pore } \\
\text { size }(\mu \mathrm{m})\end{array}$ & $\begin{array}{c}\text { Standard } \\
\text { deviation }(\mu \mathrm{m})\end{array}$ \\
\hline Pure PVC & 0 & 161.1 & 57.4 \\
Zeolite & 2.5 & 55.6 & 39.3 \\
& 5 & 96.1 & 46.9 \\
& 10 & 95.4 & 86.0 \\
& 20 & 64.0 & 44.6 \\
$\mathrm{CaCO}_{3}$ & 2.5 & 183.2 & 87.0 \\
& 5 & 310.9 & 167.0 \\
& 10 & 267.2 & 156.3 \\
$\mathrm{Cellulose}^{2}$ & 20 & 84.5 & 78.0 \\
& 2.5 & 69.9 & 23.0 \\
& 5 & 106.2 & 50.2 \\
& 10 & 96.3 & 59.0 \\
Luffa & 20 & 91.2 & 42.6 \\
& 2.5 & 105.5 & 40.2 \\
& 5 & 119.4 & 70.7 \\
& 10 & 87.7 & 57.8 \\
& 20 & 95.1 & 53.6 \\
\hline
\end{tabular}

only slightly hygroscopic, better compatibility of calcite with plastisol is expected.

\subsection{Morphology of PVC foams}

In Fig. 1, SEM micrographs of $\mathrm{Ca} / \mathrm{Zn}$ stearate stabilized PVC foams with $2.5,5,10,20 \% \mathrm{CaCO}_{3}$, and without additives are shown. Tables 1 and 2 illustrate the average pore sizes of samples and their deviations which are obtained by SEM analysis. In Fig. 1(a), formation of pores was not so regular but their sizes were very close to each other. The pore size was $280.6 \mu \mathrm{m}$. The
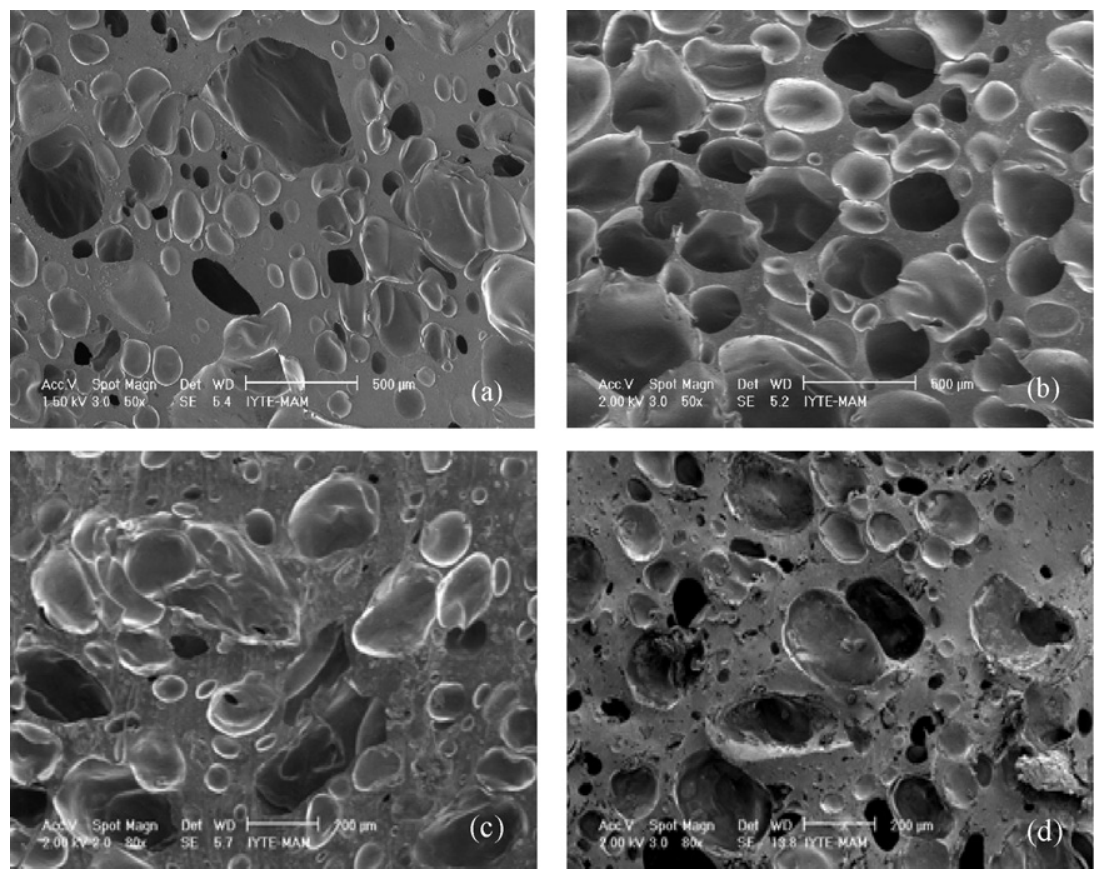

Fig. 2 - SEM micrograph of Ca/Zn stearate stabilized PVC foam: (a) $2.5 \%$ zeolite, (b) $2.5 \% \mathrm{CaCO}_{3}$, (c) $2.5 \%$ cellulose and (d) $2.5 \%$ luffa. 
standard deviation of the pore size was $108.2 \mu \mathrm{m}$. In Fig. 1(b), the foam had more regular pore sizes and pore shapes. The pore size was $337.3 \mu \mathrm{m}$ with standard deviation of $87.6 \mu \mathrm{m}$. In Fig. 1(c), the pore formation is very poor. The pore sizes and shapes are irregular, therefore it can be said that with the addition of $\mathrm{CaCO}_{3}$ the foam structure gets poorer. The pore size of the foam was $418.4 \mu \mathrm{m}$ with the standard deviation of $280.6 \mu \mathrm{m}$. In Fig. 1(d), the pore sizes and shapes are irregular. Also there is $\mathrm{CaCO}_{3}$ agglomeration. The pore size was $289.3 \mu \mathrm{m}$ with the standard deviation of $145.1 \mu \mathrm{m}$. The morphology of fillers added to PVC foams have shown similar characteristics and Fig. 1 can be accepted as their representative micrographs. It can be concluded from the results shown in Fig. 1 when the amount of filler was increased, structure, pore sizes and pore shapes could become more irregular. The irregularity of the pores caused to a maximum in the standard deviation as shown in Table 1.

Fig. 2 depicts the influence of fillers on foam formation. The pore sizes and shapes were irregular and it can be said that with the addition of luffa and cellulose the structure of the foam gets poorer. Moreover, agglomeration of luffa particles is observed in Fig. 2. The average pore size values of cellulose and luffa added PVC foams were close to each other. Likewise, $\mathrm{CaCO}_{3}$ or zeolite added PVC foams have close average pore size values for the $\mathrm{Ca} / \mathrm{Zn}$ stearate stabilized PVC foams. However, when we compare these two, it is observed that cellulose or luffa added PVC foams have lower average pore size values than that of $\mathrm{CaCO}_{3}$ or zeolite added ones.

In Fig. 3, SEM micrographs of PVC foams without zeolite and with 2.5, 5, 10 and 20\% zeolite including organotin stabilizer are shown. In Fig. 3(a), the size and shapes of the pores are quite regular and good cell formation is observed. The pore size was $161.1 \mu \mathrm{m}$ with the standard deviation of $57.4 \mu \mathrm{m}$. In Fig. 3(b), the cell formation was poor and foam had irregular pore sizes and pore shapes. The size pore size was $55.6 \mu \mathrm{m}$ with the standard deviation of $39.4 \mu \mathrm{m}$. In Fig. 3(c), the pore formation was better than that of in Fig. 3(b) however the pore sizes and shapes were still irregular. The pore size of the foam was $96.2 \mu \mathrm{m}$ with the standard deviation of $46.9 \mu \mathrm{m}$. In Fig. 3(d), the pore shapes are quite good but their sizes were very irregular. The pore size was $95.4 \mu \mathrm{m}$ with a standard deviation of $86.0 \mu \mathrm{m}$. In Fig. 3(e), fracture is observed noticeably with very low cell formation. The pore size was $63.95 \mu \mathrm{m}$ with a standard deviation of $44.58 \mu \mathrm{m}$.

In Fig. 4(b), formation of the pores were more than the rest of filler added organotin stabilized PVC foams and very regular and the sizes were very close to each other. The pore size was $183.2 \mu \mathrm{m}$ with standard deviation of $87.0 \mu \mathrm{m}$. In Fig. 4(a,
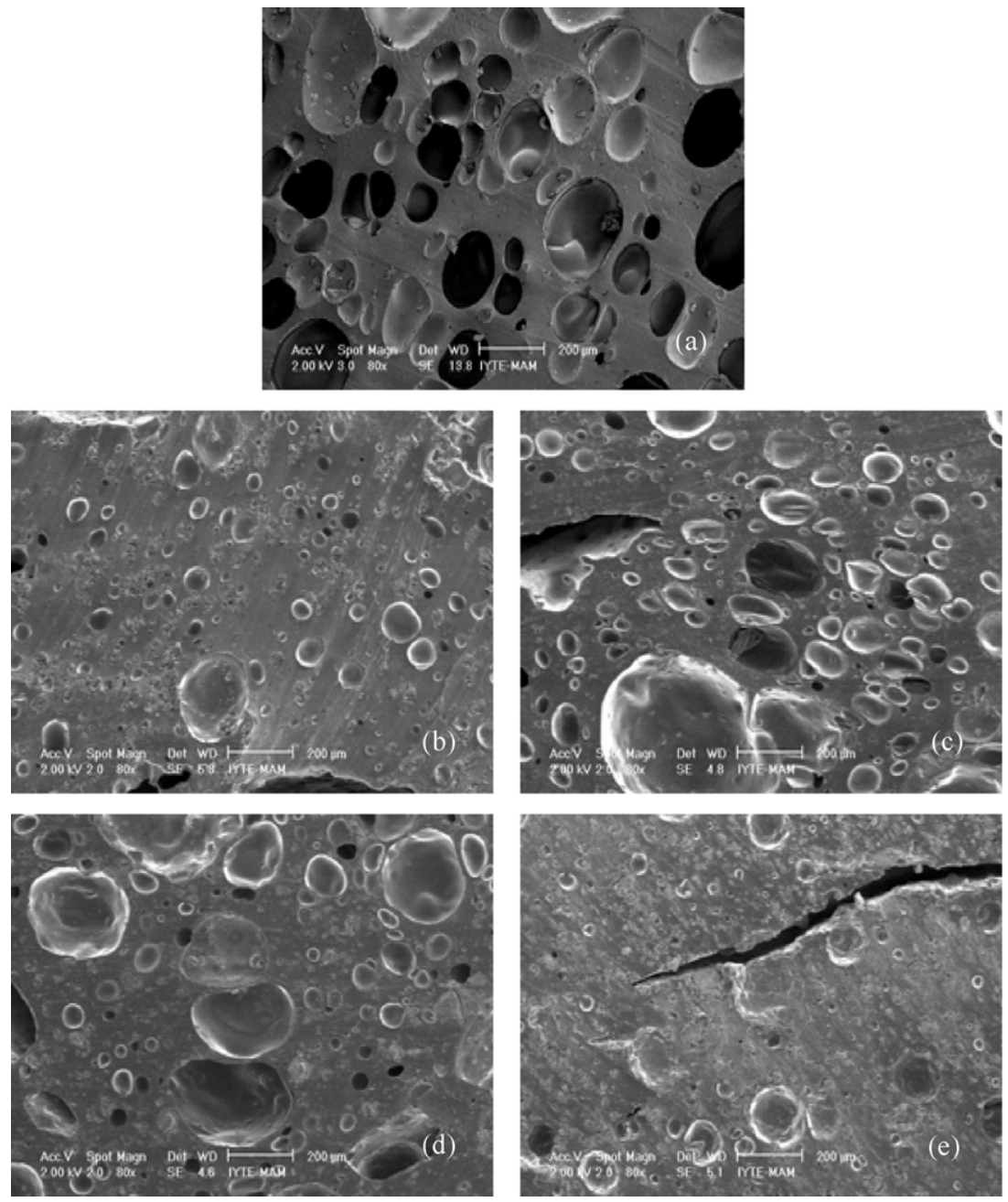

Fig. 3 - SEM micrographs of organotin stabilized PVC foams: (a) without additive, and with (b) $2.5 \%$, (c) $5 \%$, (d) $10 \%$ and (e) $20 \%$ zeolite. 

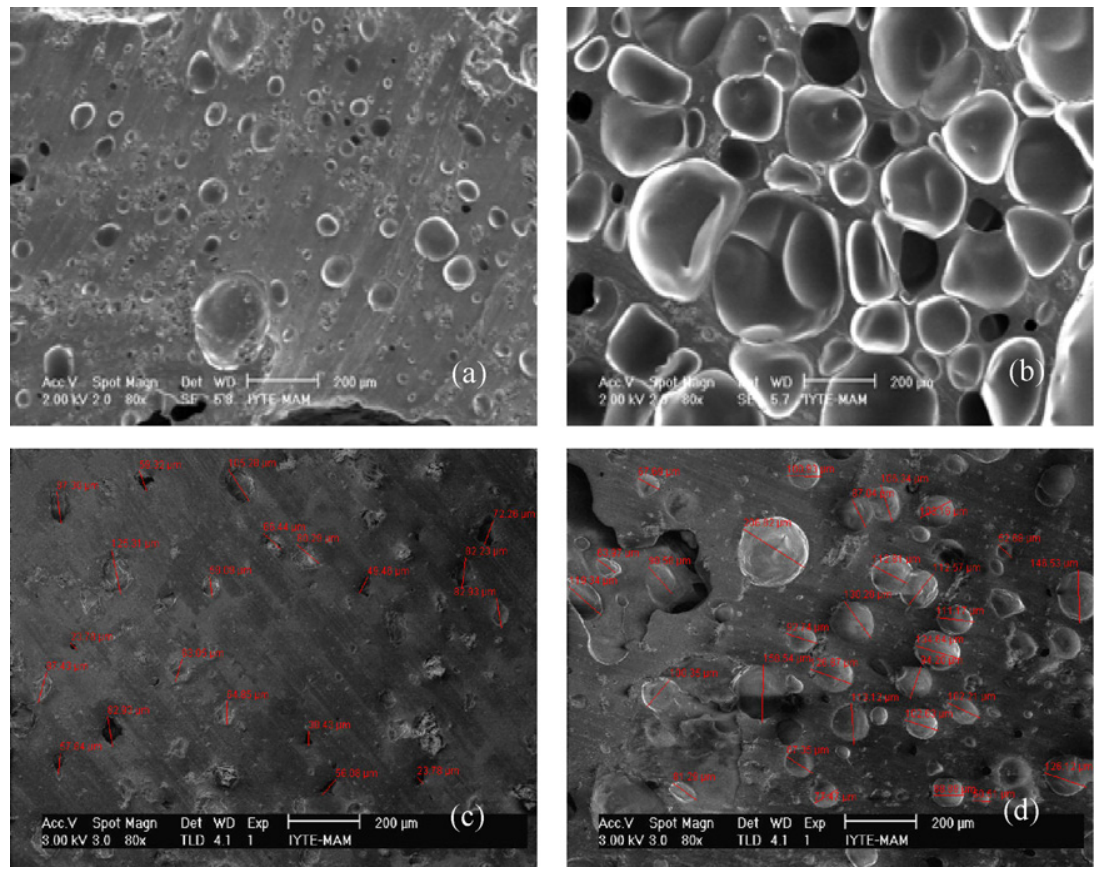

Fig. 4 - SEM micrograph of organotin stabilized PVC foam: (a) $2.5 \%$ zeolite, (b) $2.5 \% \mathrm{CaCO}_{3}$, (c) $2.5 \%$ cellulose and (d) $2.5 \%$ luffa.

c and d), pore formation was very low. It was observed that no surface pore was obtained and number of the open pores was less than that of $\mathrm{CaCO}_{3}$ added PVC foam. It can be resulted that organotin stabilizer influenced foam formation negatively except $\mathrm{CaCO}_{3}$ added PVC foam sample.

\subsection{Density and pore volume}

In Tables 3 and 4, density and pore percentages of flexible PVC foams are shown. The total pore percentages of the samples were investigated and it was found that the $\mathrm{Ca} / \mathrm{Zn}$ stearate and organotin stabilized samples with zeolite have a range from 20.55 to $55.72 \%$. The $\mathrm{Ca} / \mathrm{Zn}$ stearate stabilized sample without filler had a pore percentage of $27.47 \%$. The $\mathrm{CaCO}_{3}$ added $\mathrm{Ca} / \mathrm{Zn}$ stearate stabilized PVC foam samples had higher pore percentages than that of rest of samples with $\mathrm{Ca} / \mathrm{Zn}$ stearate and the range was between 53.48 and $91.42 \%$. For both $\mathrm{Ca} / \mathrm{Zn}$ stearate and organotin stabilized PVC foam, the $\mathrm{CaCO}_{3}$ gave better foam formation than zeolite. Moreover, the density of the foam without the filler with $\mathrm{Ca} / \mathrm{Zn}$

\section{Table 3 - Ca/Zn stearate stabilized foams' theoretical and experimental density, pore volume}

\begin{tabular}{|c|c|c|c|c|c|c|}
\hline Filler type & $\begin{array}{c}\text { Concentration } \\
\text { (\%) }\end{array}$ & $\begin{array}{c}\text { Theoretical } \\
\text { density }\left(\mathrm{g} / \mathrm{cm}^{3}\right)\end{array}$ & $\begin{array}{l}\text { Foam density } \\
\left(\mathrm{g} / \mathrm{cm}^{3}\right)\end{array}$ & $\begin{array}{c}\text { Total pore } \\
(\%)\end{array}$ & $\begin{array}{c}\text { Open pore } \\
(\%)\end{array}$ & $\begin{array}{c}\text { Closed pore } \\
(\%)\end{array}$ \\
\hline Pure PVC & 0 & 1.1587 & 0.8312 & 27.47 & 13.56 & 13.91 \\
\hline \multirow[t]{4}{*}{ Zeolite } & 2.5 & 1.1725 & 0.5113 & 55.72 & 15.65 & 40.07 \\
\hline & 5 & 1.1867 & 0.6623 & 43.79 & 20.89 & 22.90 \\
\hline & 10 & 1.2162 & 0.5632 & 53.08 & 26.46 & 26.62 \\
\hline & 20 & 1.2798 & 0.7344 & 43.57 & 14.90 & 28.66 \\
\hline \multirow[t]{4}{*}{$\mathrm{CaCO}_{3}$} & 2.5 & 1.1764 & 0.1512 & 86.87 & 12.17 & 74.70 \\
\hline & 5 & 1.1948 & 0.1011 & 91.42 & 14.35 & 77.07 \\
\hline & 10 & 1.2332 & 0.2101 & 82.67 & 15.22 & 67.45 \\
\hline & 20 & 1.3180 & 0.6231 & 53.48 & 16.34 & 37.14 \\
\hline \multirow[t]{4}{*}{ Cellulose } & 2.5 & 1.1637 & 0.8152 & 29.95 & 8.91 & 21.04 \\
\hline & 5 & 1.1687 & 0.8331 & 28.72 & 4.05 & 24.67 \\
\hline & 10 & 1.1790 & 0.8555 & 27.44 & 4.87 & 22.57 \\
\hline & 20 & 1.2000 & 0.8344 & 30.46 & 5.97 & 24.50 \\
\hline \multirow[t]{4}{*}{ Luffa } & 2.5 & 1.1651 & 0.8400 & 27.90 & 5.09 & 22.81 \\
\hline & 5 & 1.1717 & 0.8419 & 28.15 & 3.63 & 24.51 \\
\hline & 10 & 1.1850 & 0.8750 & 26.16 & 6.31 & 19.84 \\
\hline & 20 & 1.2126 & 0.9174 & 24.35 & 3.39 & 20.95 \\
\hline
\end{tabular}




\begin{tabular}{|c|c|c|c|c|c|c|}
\hline Filler type & $\begin{array}{c}\text { Concentration } \\
\text { (\%) }\end{array}$ & $\begin{array}{c}\text { Theoretical } \\
\text { density }\left(\mathrm{g} / \mathrm{cm}^{3}\right)\end{array}$ & $\begin{array}{l}\text { Foam density } \\
\qquad\left(\mathrm{g} / \mathrm{cm}^{3}\right)\end{array}$ & $\begin{array}{l}\text { Total pore } \\
\text { (\%) }\end{array}$ & $\begin{array}{c}\text { Open pore } \\
(\%)\end{array}$ & $\begin{array}{c}\text { Closed pore } \\
(\%)\end{array}$ \\
\hline Pure PVC & 0 & 1.1818 & 1.0340 & 12.53 & 1.95 & 10.58 \\
\hline \multirow[t]{4}{*}{ Zeolite } & 2.5 & 1.1956 & 0.9356 & 21.75 & 2.44 & 19.31 \\
\hline & 5 & 1.2098 & 0.9213 & 23.84 & 3.55 & 20.29 \\
\hline & 10 & 1.2391 & 0.8201 & 33.81 & 4.09 & 29.73 \\
\hline & 20 & 1.3023 & 1.0347 & 20.55 & 2.50 & 18.04 \\
\hline \multirow[t]{4}{*}{$\mathrm{CaCO}_{3}$} & 2.5 & 1.1997 & 0.9205 & 23.27 & 6.32 & 16.96 \\
\hline & 5 & 1.2181 & 0.9591 & 21.26 & 11.04 & 10.23 \\
\hline & 10 & 1.2568 & 0.9992 & 20.49 & 7.49 & 13.01 \\
\hline & 20 & 1.3419 & 1.1084 & 17.40 & 3.88 & 13.52 \\
\hline \multirow[t]{4}{*}{ Cellulose } & 2.5 & 1.1864 & 1.0871 & 8.38 & 0.13 & 8.25 \\
\hline & 5 & 1.1911 & 1.0472 & 12.12 & 0.46 & 11.66 \\
\hline & 10 & 1.2005 & 1.0741 & 11.72 & 0.54 & 11.19 \\
\hline & 20 & 1.2198 & 1.0708 & 12.22 & 0.88 & 11.34 \\
\hline \multirow[t]{4}{*}{ Luffa } & 2.5 & 1.1879 & 1.0038 & 15.50 & 0.64 & 14.86 \\
\hline & 5 & 1.1941 & 1.0315 & 13.62 & 0.51 & 13.41 \\
\hline & 10 & 1.2068 & 1.0439 & 13.50 & 1.42 & 12.08 \\
\hline & 20 & 1.2328 & 1.1176 & 9.34 & 2.92 & 6.42 \\
\hline
\end{tabular}

stearate was calculated as $0.8312 \mathrm{~g} / \mathrm{cm}^{3}$. Densities decreased with the addition of fillers, i.e. zeolite and $\mathrm{CaCO}_{3}$. The density of the $\mathrm{Ca} / \mathrm{Zn}$ stearate stabilized PVC foam samples decreased to $0.5113 \mathrm{~g} / \mathrm{cm}^{3}$ with the addition of zeolite. The maximum pore percentage was observed as $91.42 \%$ on the $\mathrm{Ca} / \mathrm{Zn}$ stearate stabilized PVC foam having $5 \% \mathrm{CaCO}_{3}$ and the density of this sample was $0.1011 \mathrm{~g} / \mathrm{cm}^{3}$. According to the results, organotin stabilizer reduced the foam formation of $\mathrm{CaCO}_{3}$ and zeolite added PVC foam and the best formation were observed on the $\mathrm{Ca} / \mathrm{Zn}$ stearate stabilized PVC foam having $5 \% \mathrm{CaCO}_{3}$.

When the total pore percentages of the samples were investigated it is observed that, $\mathrm{Ca} / \mathrm{Zn}$ stearate and organotin stabilized samples with cellulose have a range from 8.38 to $30.46 \%$. The maximum percentage was observed on the sample with $20 \%$ cellulose. Both of the samples containing luffa had approximately close pore percentage than that of samples with cellulose for both $\mathrm{Ca} / \mathrm{Zn}$ stearate and organotin stabilized PVC foam samples and the range was between 9.34 and $28.15 \%$. The $\mathrm{Ca} / \mathrm{Zn}$ stearate stabilized foam produced with $5 \%$ luffa had the percentage of $28.15 \%$. The densities of the foams were calculated and given in Table 2 . The density of the foam without the filler was calculated as $1.034 \mathrm{~g} / \mathrm{cm}^{3}$. It is observed that, densities increased with the addition of cellulose and luffa fillers. But this increment is so small. The maximum den- sity was observed on the foam with $20 \%$ luffa and the value was calculated as $1.1176 \mathrm{~g} / \mathrm{cm}^{3}$. The minimum density was observed on the foam with $2.5 \%$ cellulose and the value was calculated as $0.8152 \mathrm{~g} / \mathrm{cm}^{3}$.

As a result, when the cellulose amount or luffa amount is increased, structure pore sizes and pore shapes will be more irregular. Therefore, it is not suitable to add cellulose or luffa in high amounts to the PVC foam for practical applications such as thermal insulation and construction field. Mengeloğlu et al. showed that the density and the average cell size of the PVC foam without any filler were $0.66 \mathrm{~g} / \mathrm{cm}^{3}$ and $74 \mu \mathrm{m}$, while the density and the average cell size of 30 parts 100 mesh wood fiber added PVC foam were $0.93 \mathrm{~g} / \mathrm{cm}^{3}$ and $44 \mu \mathrm{m}$ (Mengeloglu and Matuana, 2001). Luffa is more suitable filler than both cellulose and wood flour since cell size of luffa-PVC foam higher than that of wood added PVC foams and luffa fiber is natural and cheaper than pure cellulose. The $\mathrm{Ca} / \mathrm{Zn}$ stearate stabilizer is again more suitable than organotin stabilizer for production of cellulose and luffa added PVC foam.

\subsection{Mechanical tests}

Fig. 5 shows the representative stress strain behaviors of the foam samples. Zeolite addition made the foams harder and

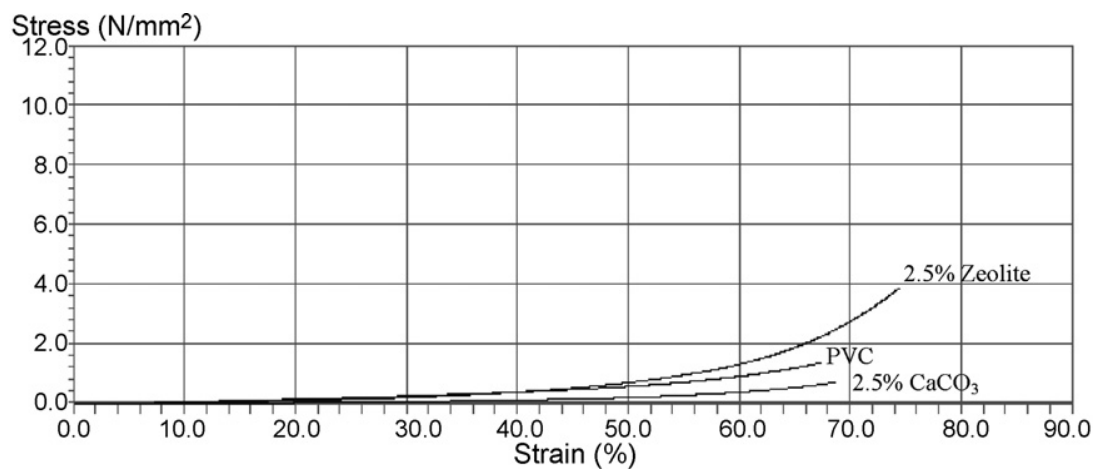

Fig. 5 - Representative stress-strain diagrams of foam samples. 


\begin{tabular}{|c|c|c|c|c|}
\hline Filler type & $\begin{array}{c}\text { Concentration } \\
(\%)\end{array}$ & $\begin{array}{l}\text { Young modulus } \\
\qquad\left(\mathrm{N} / \mathrm{mm}^{2}\right)\end{array}$ & $\begin{array}{l}\text { Compressive } \\
\text { strain (\%) }\end{array}$ & $\begin{array}{c}\text { Compressive stress } \\
\left(\mathrm{N} / \mathrm{mm}^{2}\right)\end{array}$ \\
\hline None & 0 & 1.53 & 58.19 & 1.59 \\
\hline \multirow[t]{4}{*}{ Zeolite } & 2.5 & 3.70 & 63.66 & 2.49 \\
\hline & 5 & 5.13 & 67.99 & 4.41 \\
\hline & 10 & 5.53 & 57.19 & 4.45 \\
\hline & 20 & 8.67 & 62.18 & 6.55 \\
\hline \multirow[t]{4}{*}{$\mathrm{CaCO}_{3}$} & 2.5 & 0.84 & 64.16 & 0.76 \\
\hline & 5 & 0.52 & 62.07 & 0.48 \\
\hline & 10 & 0.70 & 65.78 & 0.78 \\
\hline & 20 & 0.65 & 64.20 & 0.71 \\
\hline \multirow[t]{4}{*}{ Cellulose } & 2.5 & 4.82 & 64.21 & 3.89 \\
\hline & 5 & 4.79 & 54.86 & 4.79 \\
\hline & 10 & 4.73 & 62.26 & 4.73 \\
\hline & 20 & 7.18 & 45.29 & 7.18 \\
\hline \multirow[t]{4}{*}{ Luffa } & 2.5 & 4.84 & 58.66 & 4.84 \\
\hline & 5 & 5.09 & 55.47 & 5.10 \\
\hline & 10 & 7.03 & 49.26 & 7.03 \\
\hline & 20 & 8.14 & 48.53 & 8.19 \\
\hline
\end{tabular}

therefore the strength of the zeolite added foams to the compression are higher than the other samples. PVC foam without filler gave worse results than zeolite added foams. Since $\mathrm{CaCO}_{3}$ addition caused more foam formation, the strength to the compression was less.

Young's modulus of values for the samples that stabilized with $\mathrm{Ca} / \mathrm{Zn}$ stearate is shown in Table 5 . The foams with zeolite have the highest Young's modulus values and the average values change between 3.70 and $8.67 \mathrm{~N} / \mathrm{mm}^{2}$. PVC foam without filler has less modulus than the foams with zeolite. The Young's modulus for PVC foam is $1.53 \mathrm{~N} / \mathrm{mm}^{2}$. The foams with luffa have Young's modulus values between 4.84 and $8.14 \mathrm{~N} / \mathrm{mm}^{2}$, which are higher than the Young's modulus values of foams with cellulose 3.70 and $8.67 \mathrm{~N} / \mathrm{mm}^{2}$. PVC foams with $\mathrm{CaCO}_{3}$ filler have the lowest average Young's mod- ulus changing between 0.84 and $0.65 \mathrm{~N} / \mathrm{mm}^{2}$ which can be explained with the positive effect of $\mathrm{CaCO}_{3}$ on foam formation because of $\mathrm{CaCO}_{3}$ causing increase on the foam formation.

Young's modulus values for the samples that stabilized with organotin were shown in Table 6 . Three specimens were used for the compression tests. The foams with cellulose have the highest Young's modulus values and the average values change between 12.29 and $15.28 \mathrm{~N} / \mathrm{mm}^{2}$. PVC foam without filler has less modulus than the foams with cellulose. The Young's modulus for pure PVC foam is $2.20 \mathrm{~N} / \mathrm{mm}^{2}$. Young's modulus of PVC foams with luffa filler has lower value than PVC foams with cellulose filler and they change between 9.06 and $10.98 \mathrm{~N} / \mathrm{mm}^{2}$. The foams with zeolite filler have Young's modulus values higher than the foams with $\mathrm{CaCO}_{3}$ filler and the values change between 4.68 and $8.21 \mathrm{~N} / \mathrm{mm}^{2}$. PVC foams

\section{Table 6 - Mechanical properties of the organotin stabilized samples}

\begin{tabular}{|c|c|c|c|c|}
\hline Filler type & $\begin{array}{c}\text { Concentration } \\
(\%)\end{array}$ & $\begin{array}{l}\text { Young modulus } \\
\left(\mathrm{N} / \mathrm{mm}^{2}\right)\end{array}$ & $\begin{array}{l}\text { Compressive } \\
\text { strain (\%) }\end{array}$ & $\begin{array}{c}\text { Compressive stress } \\
\left(\mathrm{N} / \mathrm{mm}^{2}\right)\end{array}$ \\
\hline Pure PVC & 0 & 2.20 & 75.78 & 7.29 \\
\hline \multirow[t]{4}{*}{ Zeolite } & 2.5 & 7.82 & 64.21 & 7.15 \\
\hline & 5 & 4.68 & 62.92 & 4.28 \\
\hline & 10 & 5.24 & 55.99 & 3.60 \\
\hline & 20 & 8.21 & 56.21 & 5.26 \\
\hline \multirow[t]{4}{*}{$\mathrm{CaCO}_{3}$} & 2.5 & 4.73 & 78.40 & 3.99 \\
\hline & 5 & 2.39 & 69.12 & 1.96 \\
\hline & 10 & 3.19 & 80.62 & 2.94 \\
\hline & 20 & 5.26 & 66.00 & 5.17 \\
\hline \multirow[t]{4}{*}{ Cellulose } & 2.5 & 12.29 & 60.23 & 8.38 \\
\hline & 5 & 12.33 & 63.97 & 9.68 \\
\hline & 10 & 14.94 & 56.24 & 10.46 \\
\hline & 20 & 15.28 & 57.98 & 9.48 \\
\hline \multirow[t]{4}{*}{ Luffa } & 2.5 & 2.20 & 70.59 & 10.36 \\
\hline & 5 & 10.98 & 69.98 & 10.17 \\
\hline & 10 & 10.27 & 71.59 & 10.05 \\
\hline & 20 & 9.06 & 69.16 & 9.36 \\
\hline
\end{tabular}


with $\mathrm{CaCO}_{3}$ filler have the lowest Young's modulus changing between 2.39 and $5.26 \mathrm{~N} / \mathrm{mm}^{2}$ because $\mathrm{CaCO}_{3}$ caused increase on the foam formation. Higher Young's modulus value indicates lower foam formation. As an example, $\mathrm{Ca} / \mathrm{Zn}$ stearate stabilized PVC foams having $\mathrm{CaCO}_{3}$ has the highest foam formation and the lowest Young's modulus value.

Since Young's modulus is the load per unit deformation area and higher Young's modulus value indicates lower foam formation, the samples with $\mathrm{Ca} / \mathrm{Zn}$ stearate stabilizer which showed more foam formation than samples with organotin stabilizer, have Young's modulus values less than samples with organotin stabilizer.

The compressive deformation values for PVC foams are shown in Table 4. The deformations of the samples were very close to each other. After the yield point the deformations were around $65 \%$. The deformation values for zeolite added foams with $\mathrm{Ca} / \mathrm{Zn}$ stearate stabilizer and organotin stabilizer change between 57.19 and 63.66, and 55.99 and $64.21 \mathrm{~N} / \mathrm{mm}^{2}$, respectively. Pure PVC foam has average of $58.19 \%$. The deformation values for $\mathrm{CaCO}_{3}$ added foams with $\mathrm{Ca} / \mathrm{Zn}$ stearate stabilizer and organotin stabilizer change between 62.07 and 64.20 , and 66.00 and $80.62 \mathrm{~N} / \mathrm{mm}^{2}$, respectively.

The deformation values of $\mathrm{Ca} / \mathrm{Zn}$ stearate and organotin stabilized PVC foam samples having cellulose change between 45.29 and 64.21 , and 56.24 and $63.97 \mathrm{~N} / \mathrm{mm}^{2}$, respectively. The deformation values of $\mathrm{Ca} / \mathrm{Zn}$ stearate and organotin stabilized PVC foam samples having luffa change between 48.53 and 58.66 , and 69.16 and $71.59 \mathrm{~N} / \mathrm{mm}^{2}$, respectively.

The deformation values for foams with $\mathrm{Ca} / \mathrm{Zn}$ stearate stabilizer are lower than the values for foams with organotin stabilizer because the pore volumes of foams with $\mathrm{Ca} / \mathrm{Zn}$ stearate stabilizer are high, so that they collapse immediately and this causes their strain values to become lower.

Table 5 shows the stress value of PVC foams. The average stress values of $\mathrm{Ca} / \mathrm{Zn}$ stearate and organotin stabilized PVC foam samples having zeolite change between 2.49 and 6.55 , and 3.60 and $7.15 \mathrm{~N} / \mathrm{mm}^{2}$, respectively. PVC foam without filler has a stress of $1.59 \mathrm{~N} / \mathrm{mm}^{2}$. The average stress values for $\mathrm{CaCO}_{3}$ added samples with $\mathrm{Ca} / \mathrm{Zn}$ stearate stabilizer and organotin stabilizer change between 0.48 and 0.78 , and 1.96 and $5.17 \mathrm{~N} / \mathrm{mm}^{2}$, respectively. Similar to the Young's modulus values, the stress of $\mathrm{Ca} / \mathrm{Zn}$ stearate or organotin stabilized and $\mathrm{CaCO}_{3}$ added samples are lower than that of rest of samples. Zeolite added foams can hold more stress because the addition of zeolite makes the foam harder. The results found are the expected results for our case.

The average stress values of $\mathrm{Ca} / \mathrm{Zn}$ stearate and organotin stabilized PVC foam samples having cellulose change between 3.89 and 7.17, and 9.48 and $10.46 \mathrm{~N} / \mathrm{mm}^{2}$, respectively. PVC foam without filler has a stress of $7.29 \mathrm{~N} / \mathrm{mm}^{2}$. The average stress values of $\mathrm{Ca} / \mathrm{Zn}$ stearate and organotin stabilized PVC foam samples having luffa change between 4.84 and 8.19, and 9.36 and $10.36 \mathrm{~N} / \mathrm{mm}^{2}$, respectively. Both cellulose and luffa added foams can hold more stress because the addition of cellulose makes the foam harder.

\subsection{Water uptake}

Water uptake capacities of $\mathrm{Ca} / \mathrm{Zn}$ stearate and organotin stabilized PVC foam without and with filler are shown in

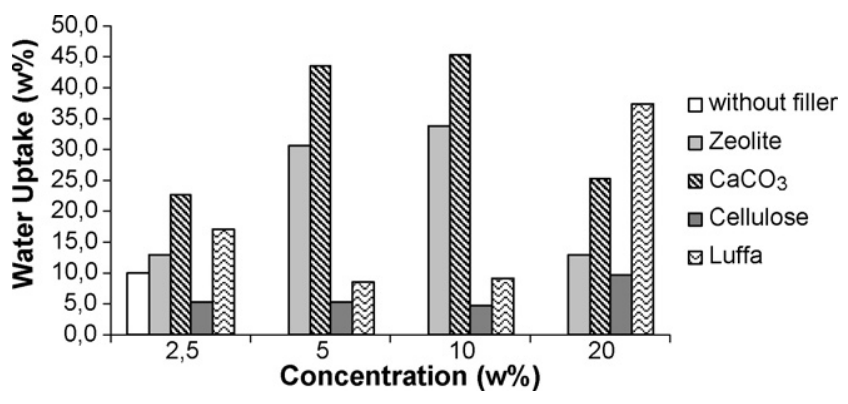

Fig. 6 - Water uptake capacities of organotin stabilized PVC foams.

Figs. 6 and 7. Water uptake of PVC foams at time $t$ is calculated using Eq. (9).

$\%$ Uptake $=\frac{M_{t}-M_{0}}{M_{0}} \times 100$

where $M_{t}$ is the mass of sample at time $t$ and $M_{0}$ is the mass of sample at $t=0$.

PVC foams that stabilized with organotin and $\mathrm{Ca} / \mathrm{Zn}$ stearate without filler have ability to uptake water because it has pores on the surface and water gets into these pores. The both organotin and $\mathrm{Ca} / \mathrm{Zn}$ stearate stabilized PVC foams without filler have 10.1 and $23.2 \%$ water uptake capacity, respectively. Cellulose and luffa-based PVC foam samples for each stabilizer has water uptake capacity with a wide range from 4.7 to $43.7 \%$. For cellulose and luffa added PVC foams, water uptake results indicate that organotin stabilized samples show poor water uptake capacities than $\mathrm{Ca} / \mathrm{Zn}$ stearate stabilized samples. This situation may be related to the total pore volume. As mentioned before, the pore volume of $\mathrm{Ca} / \mathrm{Zn}$ stearate stabilized PVC samples was higher than that of organotin stabilized PVC samples. The similar results were observed in $\mathrm{CaCO}_{3}$ and zeolite added PVC foams. The water uptake capacities of $\mathrm{Ca} / \mathrm{Zn}$ stearate stabilized PVC samples were relatively higher than that of organotin stabilized PVC samples. The water uptake capacity of $\mathrm{Ca} / \mathrm{Zn}$ stearate stabilized PVC foam having $20 \% \mathrm{CaCO}_{3}$ was $75.6 \%$ which was maximum water uptake capacity among the all PVC foams. The main factors affecting the water uptake capacity should be total pore volume of sample and rate of open pore to closed pore volume. The results of pore volume and water uptake capacity exhibit consistency.

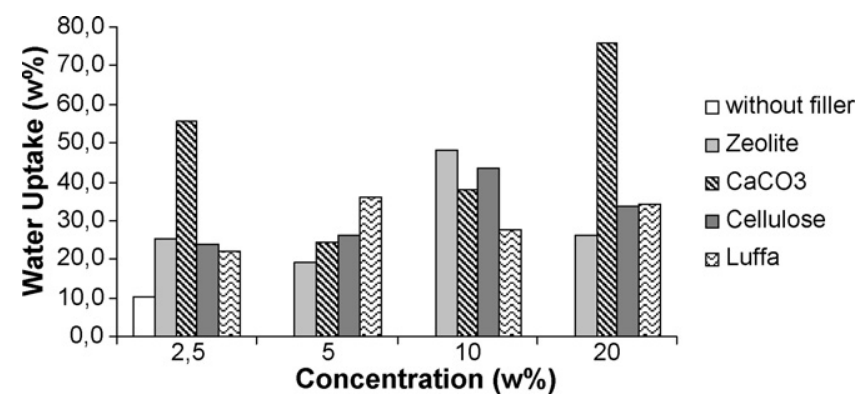

Fig. 7 - Water uptake capacities of Ca-Zn stearate stabilized PVC foams. 


\section{Conclusions}

The average pore sizes of cellulose or luffa added PVC foam which have similar average pore sizes was observed to be lower than $\mathrm{CaCO}_{3}$ or zeolite added PVC foam having similar average pore sizes for both organotin and $\mathrm{Ca} / \mathrm{Zn}$ stearate stabilizers. Morphology of the sample without any filler showed that use of organotin stabilizers instead of $\mathrm{Ca} / \mathrm{Zn}$ stearate stabilizers decreased foam formation, pore sizes and regularity in pore size distribution. Best pore size distribution and maximum pore volume percentage was observed in the $\mathrm{Ca} / \mathrm{Zn}$ stearate stabilized PVC foam having $5 \% \mathrm{CaCO}_{3}$ with $337.3 \mu \mathrm{m}$ average pore size and $91 \%$ pore volume.

Finally, at low filler concentration, filler acts as nucleating agent and increased the foam formation. The structure of PVC foams becomes rigid and strong at high filler concentration. It is observed that the properties of cellulose or luffa added foam are not suitable for practical foam applications such as thermal insulation and construction field. But they, especially the $\mathrm{Ca} / \mathrm{Zn}$ stearate stabilized PVC foams, can be used in plant watering equipments (perspiration, drip irrigation) since water uptake capacity of $\mathrm{Ca} / \mathrm{Zn}$ stearate stabilized PVC foams having luffa or cellulose is sufficiently high. Zeolite and $\mathrm{CaCO}_{3}$ added PVC foams that stabilized with $\mathrm{Ca} / \mathrm{Zn}$ stearate can be used in sandwich panel which widely used for construction prefabricate buildings (such as house, fabrics, container, warehouse, etc.) since zeolite and $\mathrm{CaCO}_{3}$ added PVC foams have rigid structure.

\section{Acknowledgements}

This study was supported by Izmir Institute of Technology, Project number 2003 IYTE 41. The contributions of undergrad- uate students Parlayan G., Köseler C., Meriçoğlu N., Uluçay N., Mengüloğul A. and Erciyeş G. are greatly acknowledged by the authors.

\section{REFERENCES}

Arkiş, E., Balköse, D., 2005. Thermal stabilisation of poly(vinyl chloride) by organotin compounds. Polym. Degrad. Stab. 88, 46-55.

ASTM Standard: D1621-73, Standard test method for compressive properties of rigid cellular plastics, 1979.

Balköse, D., Gökçel, H.I., Göktepe, S.E., 2001. Synergism of Ca/Zn soaps in poly(vinyl chloride) thermal stability. Eur. Polym. J. 37, 1191-1197.

Berins, L.M., Bunten, M.J., Nerman, M.W., Smallwood, P.V., Stephenson, R.C., 1982. PVC its production and use. Encyclopedia of Polymer Science and Engineering, vol. 17.

Brathun, R., Zingsheim, P., 1991. In: Klempner, D., Frisch, K. (Eds.), Handbook of Polymeric Foams and Foam Technology. Hanser, Munich, p. 245 (Chapter 10).

Gaechter, R., Müller, H., 1993. Plastic Additives, fourth ed. Hanser/Gardner, Cincinnati.

Hensen, F., 1997. Plastics Extrusion Technology. Hanser/Gardner.

Matuana, L.M., Balatinecz, J.J., Park, C.B., 1998. Effect of surface properties on the adhesion between PVC and wood veneer laminates. Polym. Eng. Sci. 38, 765.

Mengeloglu, F., Matuana, L.M., 2001. Foaming of rigid PVC/wood-flour composites through a continuous extrusion process. J. Vinyl Additive Technol. 7, 142-148.

Patterson, J., 2001. New opportunities with wood-flour-foamed PVC. J. Vinyl Additive Technol. 7, 138-141.

Saechtling, H.J., 1987. Plastics Handbook. Carl Hanser Verlag.

Sartorius Density Determination Kit User's Manual, Sartorius AG, Goettingen, (1992).

Yanez-Flores, I.G., Ibarra-Gomez, R., Rodriguez-Fernandez, O.S., Gilbert, M., 2000. Peroxide crosslinking of PVC foam formulation. Eur. Polym. J. 36, 2235-2241. 